\title{
Optimized Conditions of Model Processing for Ready-to-eat Style Galbi-jjim Prepared by Sous-vide and Cook-chill System
}

\author{
Kyeong Mi Kim¹, Jin-Hee Park², and Weon-Sun Shin* \\ Department of Food and Nutrition, Hanyang University, Seoul 133-791, Korea \\ ${ }^{1}$ Research Institute of Food, OURHOME, Seongnam 462-819, Korea \\ ${ }^{2}$ Neo Food Resources Research Group, Korea Food Research Institute, Seongnam 463-746, Korea
}

\begin{abstract}
To develop ready-to-eat (RTE) style Korean traditional Galbi-jjim, the optimal conditions for sous-vide cooking and cookchill preparation and the sensory properties of the cooked products were investigated. During heating, the meat core temperatures reached $85^{\circ} \mathrm{C}$ within $30 \mathrm{~min}$ and $45 \mathrm{~min}$ when a water bath and combination oven were used, respectively. Chilling to $3^{\circ} \mathrm{C}$ within 45 min was conducted to meet the standards for microbiological safety set by the UK Department of Health and Social Security (DHSS) Guideline. Galbi-jjim that was vacuum-cooked in a water bath was much more tender than that of Galbi-jjim prepared using the cook-chill method, but had no difference in any reheating methods. The average sensory scores of juiciness and the overall acceptance of Galbi-jjim were significantly higher when water bath cooking was used, and there were no differences in reheating methods. In conclusion, the serial methods of sous-vide processing and rapid chilling can be applied to produce RTE traditional Galbi-jjim, and this can be conducted while meeting the standards specified in safety guidelines.
\end{abstract}

Key words: Galbi-jjim, sous-vide, cookchill, model processing, safety guideline

\section{Introduction}

Recently, the consumption of refrigerated Ready-ToEat (RTE) type of convenient foods has been remarkably increased worldwide due to dual career family, single mother, single people and senior households (Nyati, 2000). Min (2003) reported that Korean food was introduced to foreigners as healthy and low caloric food. According to Choi (2004) native consumption have preferred the meat ("Galbi") for outside the home or menu, and widely known Korean food to foreigner were indicated that "Kimchi" (17.5\%), "Bulgogi" (15.6\%) and "Galbi" (15.1\%). Also, the frequency of domestic consumer's using the restaurant and buying the ready-made foods from the market has been markedly increased (Lee et al., 2007). Therefore, the fresh-type ready meals have a significant market potential, and then developing the precooked or ready-cooked food product is necessary.

"Galbi-jjim" is a representative Korean traditional food,

*Corresponding author : Weon-Sun Shin, Department of Food and Nutrition, Hanyang University, Seoul 133-791, Korea. Tel: 82-2-2220-1204, Fax: 82-2-2292-1226, E-mail: hime@hanyang. ac.kr which the seasoned beef short ribs with kinds of vegetables are braised in the pressure cooker. Generally, many Korean traditional dishes including "Galbi-jjim" require time-consuming and labor-intensive processing in their preparation and cooking. Thus, simplified processing and standardized recipes should be developed, and then sousvide/cookchill(SV/CC) system can be most applicable to produce the ready-to-heat type Korean traditional foods.

Sous-vide cooking system is defined as raw or partially cooked materials packed with thermostable pouch or container under vacuum condition. This processing is usually performed in the lower temperature $\left(65-95^{\circ} \mathrm{C}\right)$ and longer cooking time needed than in the conventional processing (Food Code, 2005; Hauben, 1999; Schelleken, 1996; Vaudagna et al., 2007), and then the cooked products are rapidly chilled, and stored at the temperature below $0-3^{\circ} \mathrm{C}$ for up to 3-5weeks before reheated for serve (Nyati, 2000; Vaudagna et al., 2002). Recently, sous-vide cooking and cookchill system is mostly used in the catering and foodservice sectors, because of its beneficial effect on the economic, labor cost, food quality, and marketing (Creed and Reeve, 1998), and has superior sensory and nutritional quality by vacuum packing (Creed, 1998). Despite of several advantages described above, the micro- 
biological safety should be concerned to produce the highly qualified products processed by sous-vide and cookchill system. According to Nyati (2000) and GonzálezFandos $(2004,2005)$, there are four main factors to determine the potential microbiological hazards of sous-vide products are (i) intense heat treatment of lethality value and monitored time/temperature (ii) rapid and monitored chilling, below $3^{\circ} \mathrm{C}$ (iii) chilled storage temperature and (iv) any leaks in the pouch enable to sous-vide/cookchill post-thermal processing contamination with pathogens.

Over the years, many researchers have studied for developing the convenient product processed by sousvide cooking and cookchill system such as meat products (Armstrong and McIlveen, 2000; Cho et al., 2005; Galimpin-Johan et al., 2007; Jang and Lee, 2005; Jang et al., 2006; Paik et al., 2006; Vaudagna et al., 2002; Vaudagna et al., 2007), fish products (González-Fandos et al., 2004; González-Fandos et al., 2005) and vegetable products (Kim et al., 2001; Koo et al., 2008; Song and Kim, 2007a; Song and Kim, 2007b). However, very few reports are available for minimally processed Korean traditional foods applied by sous-vide and cookchill system (Kim et al., 2001; Koo et al., 2008; Jang and Lee, 2005). In addition, less information is available on the physicochemical and sensory aspects that may be crucial in the spoilage of sous-vide meat-based dishes stored in refrigerated conditions.

The objective of this study is to develop the optimal recipe for RTE-type "Galbi-jjim" by using sous-vide and cookchill method and to evaluate the textural and sensory qualities of "Galbi-jjim".

\section{Materials and Methods}

\section{Materials}

Short beef ribs $(5 \mathrm{~cm}$-length) were purchased from a local market (Seoul, Korea) and stored in the freezer at $-20^{\circ} \mathrm{C}$ freezer until use. The soy sauce, sugar, pepper and vegetables for seasoning and marinating the beef short ribs ("Galbi") were from a local market and stored at $3^{\circ} \mathrm{C}$ until use.

\section{Formulation and preparation of Galbi-jjim}

The "Galbi-jjim" was prepared as described in Fig. 1. Briefly, the short beef ribs were sunk in the cold water to remove the blood, and then two hundreds fifty grams of the short beef ribs were boiled in $750 \mathrm{~mL}$ of hot water for 10, 20, 40 and $60 \mathrm{~min}$ in order to tenderize the meat texture and to eliminate the off-flavor. The boiled beef ribs were marinated in $253 \mathrm{~g}$ of the Galbi-jjim sauce (Table 1)

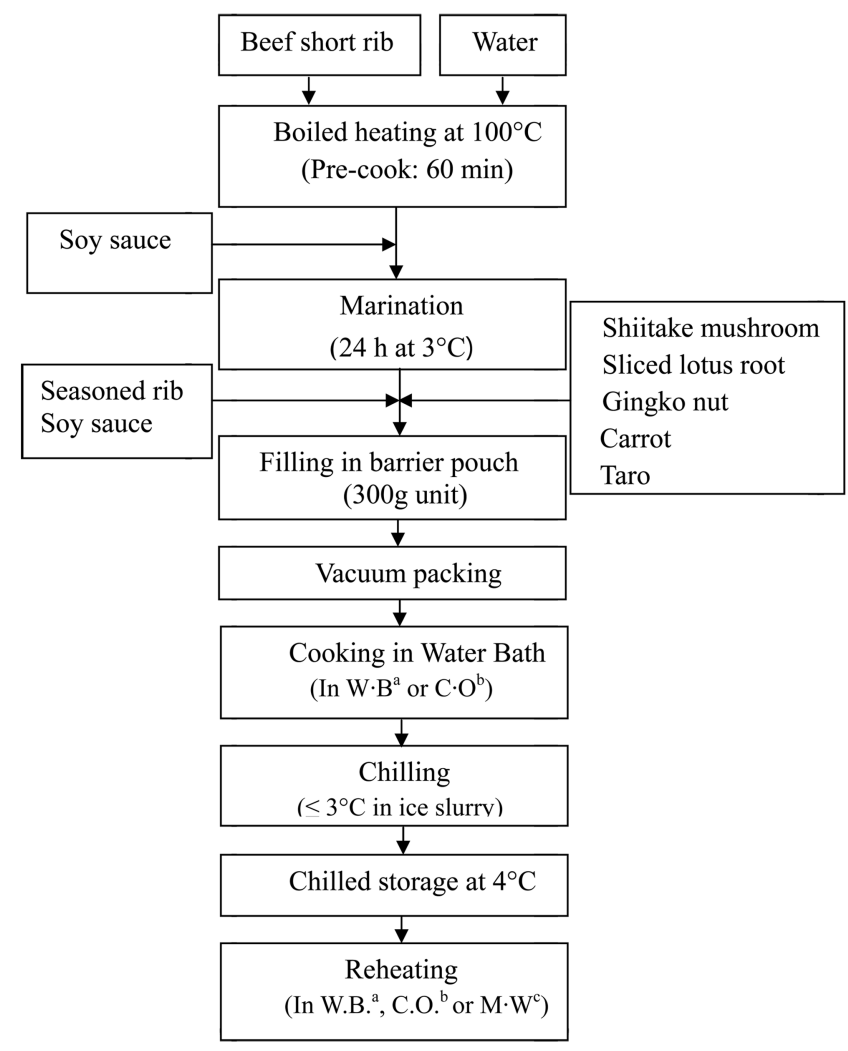

Fig. 1. Schematic process of sous-vide and cookchill for Korean traditional Galbi-jjim. W.B.: water-bath, C.O.: combination oven, M.W: microwave oven.

Table 1. Formulation of Galbi-jjim sauce

\begin{tabular}{lc}
\hline \hline Seasoning soy sauce (Raw material) & Contents (\%) \\
\hline Soy sauce & 24.24 \\
Water & 24.24 \\
Corn syrup & 20.47 \\
Sugar & 13.27 \\
Distilled liquor (soju) & 10.77 \\
Grounded pear & 3.38 \\
Grounded green onion & 1.82 \\
Grounded garlic & 1.08 \\
Grounded ginger & 0.13 \\
Sesame & 0.20 \\
Sesame oil & 0.20 \\
Black pepper & 0.20 \\
\hline \multicolumn{2}{c}{ Total } \\
\hline
\end{tabular}

at $3^{\circ} \mathrm{C}$ for $24 \mathrm{hr}$. As a control, the seasoned beef short ribs were mixed with moderately blanched vegetables such as cube-cut carrot, gingko nut, peeled taro, shiitake mushroom and sliced lotus root, and theses were individually packed in an aluminum foil sheet, and then cooked in a conventional pressure cooker for $45 \mathrm{~min}$.

\section{Sous-vide and cookchill condition}

For sous-vide cooking, three hundred grams of mari- 
Table 2. Control temperature and guidelines for sous-vide cooking

\begin{tabular}{ccc}
\hline \hline Process & Internal temperature & \\
\hline Cooking & $85^{\circ} \mathrm{C}$ for $52 \mathrm{~min}$ & UK ACMSlines $^{2)}$ \\
Chilling & $\leq 3^{\circ} \mathrm{C}$ within $120 \mathrm{~min}$ & UK ECF $^{\mathrm{b}}$ \\
Chilled & $\leq 5^{\circ} \mathrm{C}$ & Food code, FDA $^{\mathrm{d}}$ \\
Reheating & $75^{\circ} \mathrm{C} \leq$ within $30 \mathrm{~min}$ & UK DHSS $^{\mathrm{c}}$ \\
Sensory Evaluation & $63^{\circ} \mathrm{C}$ within $15 \mathrm{~min}$ & UK DHSS $^{\mathrm{c}}$ \\
\hline
\end{tabular}

${ }^{1)}$ Safety of food recommended center temperature and time.

${ }^{2)}$ Guidelines of sous-vide/cookchill system.

${ }^{a}$ Advisory Committee on the Microbiological Safety of Food (2004).

${ }^{\mathrm{b}}$ European Chilled Food Federation (2001).

${ }^{\mathrm{c}}$ Department of Health and Social Security (2003).

${ }^{\mathrm{d}}$ Food and Drug Administration (2005). nated-beef short ribs with blanched vegetables were vacuum-packed in $18 \mathrm{~cm} \times 28 \mathrm{~cm}$ multilayered film pouches (Samhosa Co., Seoul, Korea) using a vacuum packer (Samhosa Co., Seoul, Korea) under $760 \mathrm{~mm} \mathrm{Hg}$ pressure. Vacuum-packed pouches were heated at $90^{\circ} \mathrm{C}$ for $90 \mathrm{~min}$ or $160 \mathrm{~min}$ in water-bath (JS Research Inc., Gongju, Korea) or combination oven (DBM Co., Seoul, Korea), respectively. The heating conditions for microbiologically safe sous-vide cooking in this study were guide-lined by European Chilled Food Federation (2001) and Advisory Committee on the Microbiological Safety of Food (2004) (Table 2): for heat treatment of equivalent to the $90^{\circ} \mathrm{C}$ for $10 \mathrm{~min}\left(\mathrm{a} \mathrm{z}\right.$ value of $7^{\circ} \mathrm{C}$ ) process are $52 \mathrm{~min}$ at $85^{\circ} \mathrm{C}$ or $270 \mathrm{~min}$ at $80^{\circ} \mathrm{C}(2001)$ and equivalent to the $90^{\circ} \mathrm{C}$ for 10 $\min \left(\mathrm{a} \mathrm{z}\right.$ value of $9^{\circ} \mathrm{C}$ ) process are $36 \mathrm{~min}$ at $85^{\circ} \mathrm{C}, 129$
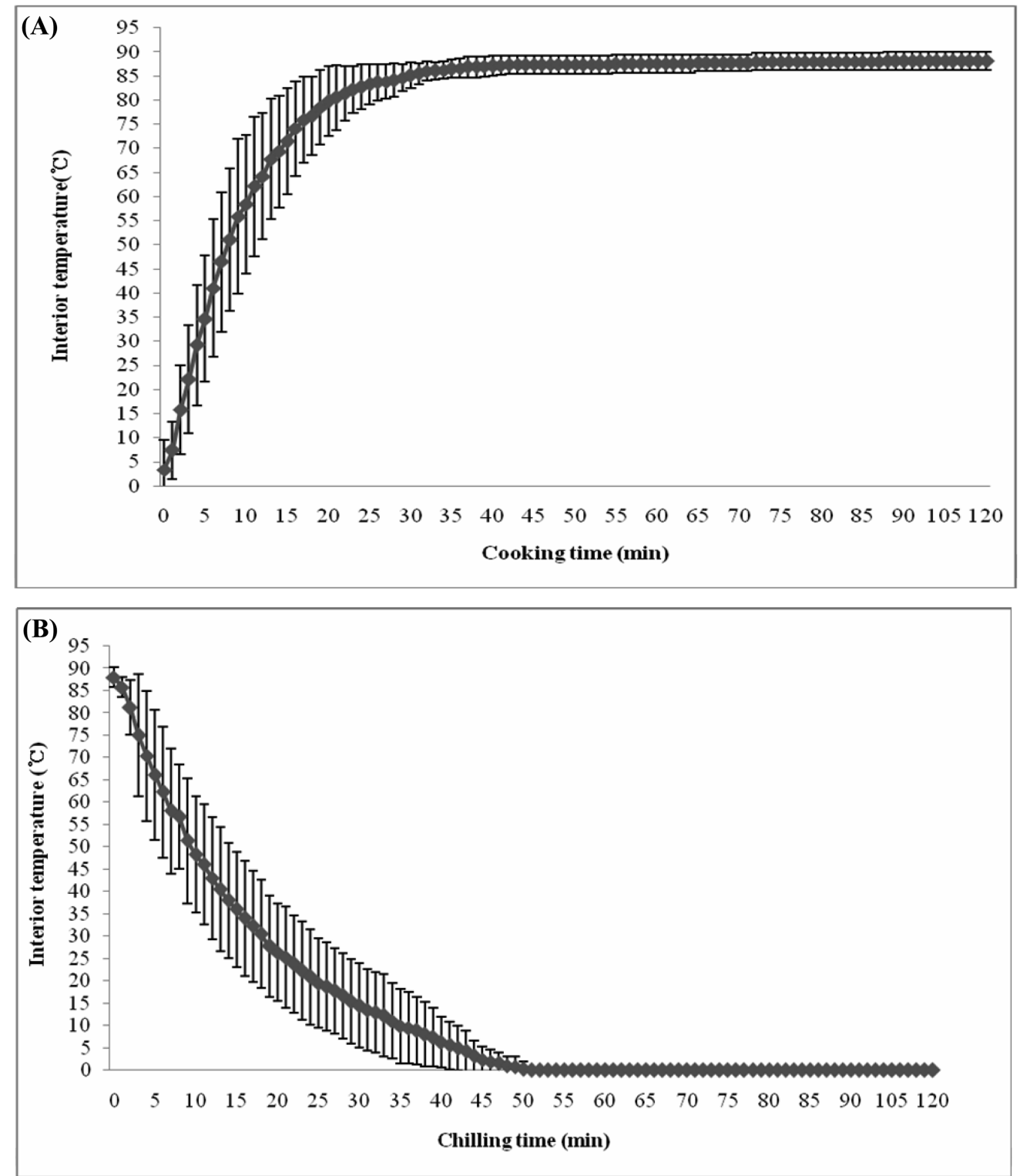

Fig. 2. (A)(B) Core temperature curves of Galbi-jijim during cooking and chilling. 
min at $80^{\circ} \mathrm{C}, 464 \mathrm{~min}$ at $75^{\circ} \mathrm{C}$ or $1,675 \mathrm{~min}$ at $70^{\circ} \mathrm{C}(2004)$. The core temperatures of each piece of meat $(4.93 .13 \mathrm{~cm})$ were measured by using a portable thermometer $(\mathrm{K} \& \mathrm{~B}$ Inc., Incheon, Korea) during cooking. After cooking, sousvide processed Galbi-jjims were immediately immersed in ice water below $3^{\circ} \mathrm{C}$. The chilling condition is followed by the recommendation of the Department of Health and Social Security Guidelines (2003). Chilled samples were stored at $3^{\circ} \mathrm{C}$ until reheating for sensory evaluation and further analysis.

\section{Texture profile analysis}

Texture profile analysis (TPA) was measured using a texture analyzer TA.XT 2i/25 (Stable Micro system, London, UK) at ambient temperature. For the measurements, the vacuum packed samples were warmed in a water bath at $75^{\circ} \mathrm{C}$ to reach an internal temperature of $72^{\circ} \mathrm{C}$, as measured by a portable thermometer. The warmed samples were cut into $1.5 \mathrm{~cm} \times 41.5 \mathrm{~cm} \times 1.5 \mathrm{~cm}$ in size and compressed perpendicular to the meat samples with a P/50 cylindrical probe. The testing conditions were: pre-test speed $3.0 \mathrm{~mm} / \mathrm{s}$, test speed $1.0 \mathrm{~mm} / \mathrm{s}$, post-test speed 1.0 $\mathrm{mm} / \mathrm{s}$, strain $80 \%$, time $2.00 \mathrm{sec}$ and force $5.00 \mathrm{~g}$.

\section{Sensory evaluation}

For the sensory analysis, the packs of Galbi-jjim samples were reheated by using a thermometrically controlled water bath or microwave oven. Reheating condition was followed by the recommendation of Department of Health and Social Security Guidelines (2004). After reheating, the samples were placed on the ceramic plates with lid which was pre-warmed at $80^{\circ} \mathrm{C}$ in an oven for $10 \mathrm{~min}$, and immediately served to the panels.

The sensory evaluations were divided into two sections: at the first section, the trained panels evaluated the optimal condition of pre-cooking time (0,20, 40 and $60 \mathrm{~min}$ before marinating). And then, at the second section, the trained 36 panels evaluated the sensory qualities of Galbi-jjim initially prepared by either waterbath or combination oven and reheated by either waterbath or microwave oven. In addition, the consumer preference test was conducted for the attributes of appearance, odor, flavor, texture and acceptability. These attributes were scored using a point scale ranging from 9 (like extremely) to 1 (dislike extremely).

\section{Statistical analysis}

Data were subjected to analysis of variance (ANOVA) and Duncan's multiple range test $(p<0.05)$ to determine significant effects and differences among the experimental treatments. Statistical software version 12.0 (SPSS Institute, Chicago, IL, USA) was used for the analysis.

\section{Results and Discussion}

\section{Heating and cooling conditions for the sous-vide cooking Galbi-jjim}

In this study, the heat treatment condition for microbiological control was subjected to temperature process control of ECFF $\left(\mathrm{P}_{85}^{7.0}=52 \mathrm{~min}\right)(2001)$ and $\operatorname{ACMFS}\left(\mathrm{P}_{85}^{9.0}=\right.$ $36 \mathrm{~min}$ ) (2004). Changes in an interior temperature were recorded with a portable needle-type thermometer during cooking and chilling. In the process of heating, The meat core temperatures reached at $85^{\circ} \mathrm{C}$ within $30 \mathrm{~min}$ in water bath, whereas within $45 \mathrm{~min}$ in combination oven. Thus, in order to satisfy the international standard for microbiological control, the heat treatment was performed at $90^{\circ} \mathrm{C}$ in water-bath for $90 \mathrm{~min}$ and in combination oven for 120 minutes (Fig. 2A). For chilling, the meat core temperatures reached at $\leq 3^{\circ} \mathrm{C}$ within $45 \mathrm{~min}$ in ice slurry (Fig. 2B). In this study, chilling time was followed by specified requirement of DHSS (2003) in case of joint of meat product.

\section{Texture profile analysis}

Texture profiles of beef short ribs pre-cooked with 0 , 20, 40 and 60 min were shown in Table 3(A). The hardness, gumminess and chewiness of pre-cooked beef short ribs significantly decreased $(p<0.05)$ with extending of blanching time. These results are similar to those of Jang's (2005) report, which longer heated meat was tender than the shorter one. The textural characteristics obtained from different cooking methods such as water bath and combination oven were summarized in Table 3(B). Hardness and chewiness of Galbi-jjims were between $13.16 \mathrm{~kg}$ and $9.14 \mathrm{~kg}$, and 2.73 and 3.45 in combination oven and water-bath, respectively. This suggested that short beef rib cooked under water bath was much tender than combination oven $(p>0.05)$. Table $3(\mathrm{C})$ shows the average values of textural characteristics of Galbi-jjim reheated with different methods. Prior to the measurement, the samples were reheated at $90^{\circ} \mathrm{C}$ for $30 \mathrm{~min}$ in water bath, at $120^{\circ} \mathrm{C}$ for $30 \mathrm{~min}$ in combination oven and at $700 \mathrm{~W}$ for $3 \mathrm{~min}$ in microwave oven. As the results, hardness, gumminess and chewiness had no notable difference among the reheating methods $(p<0.05)$. Only, springiness value of Galbi-jjim cooked in water bath was significantly higher than in combination oven $(p<0.05)$. 
Table 3(A). The average values of the texture profile analysis of different pre-cook time

\begin{tabular}{rclccc}
\hline \hline & Hardness $(\mathrm{kg})$ & Springiness & Cohesiveness & Gumminess & Chewiness \\
\hline $0 \mathrm{~min}$ & $9.45 \pm 3.09^{\mathrm{a}}$ & $0.53 \pm 0.073^{\mathrm{bc}}$ & $0.46 \pm 0.028^{\mathrm{a}}$ & $4.38 \pm 1.59^{\mathrm{a}}$ & $2.39 \pm 1.00^{\mathrm{a}}$ \\
$20 \mathrm{~min}$ & $6.80 \pm 4.14^{\mathrm{ab}}$ & $0.65 \pm 0.83^{\mathrm{a}}$ & $0.50 \pm 0.04^{\mathrm{a}}$ & $3.53 \pm 2.37^{\mathrm{ab}}$ & $2.29 \pm 1.52^{\mathrm{ab}}$ \\
$40 \mathrm{~min}$ & $4.03 \pm 1.70^{\mathrm{bc}}$ & $0.60 \pm 0.07^{\mathrm{ab}}$ & $0.38 \pm 0.06^{\mathrm{b}}$ & $1.61 \pm 0.88^{\mathrm{bc}}$ & $1.01 \pm 0.60^{\mathrm{bc}}$ \\
$60 \mathrm{~min}$ & $2.51 \pm 1.19^{\mathrm{c}}$ & $0.46 \pm 0.04^{\mathrm{c}}$ & $0.38 \pm 0.07^{\mathrm{b}}$ & $0.92 \pm 0.48^{\mathrm{c}}$ & $0.43 \pm 0.24^{\mathrm{c}}$ \\
\hline
\end{tabular}

Data are mean \pm standard deviation.

${ }^{a b c}$ Different letters are significantly different $(p<0.05)$ by Duncan's test.

Table 3(B). The average values of the texture profile analysis of different cooking methods

\begin{tabular}{cccccc}
\hline \hline & Hardness $(\mathrm{kg})$ & Springiness & Cohesiveness & Gumminess & Chewiness \\
\hline W.B. & $9.14 \pm 0.34^{\mathrm{a}}$ & $0.64 \pm 0.10^{\mathrm{a}}$ & $0.45 \pm 0.03^{\mathrm{a}}$ & $4.27 \pm 1.96^{\mathrm{a}}$ & $2.73 \pm 1.31^{\mathrm{a}}$ \\
C.O. & $13.16 \pm 5.03^{\mathrm{a}}$ & $0.55 \pm 0.01^{\mathrm{a}}$ & $0.55 \pm 0.01^{\mathrm{a}}$ & $6.22 \pm 0.99^{\mathrm{a}}$ & $3.45 \pm 0.45^{\mathrm{a}}$ \\
\hline
\end{tabular}

Data are mean \pm standard deviation.

W.B. $=$ Water-bath, C.O. $=$ Combination oven .

${ }^{\mathrm{abc}}$ Different letters are significantly different $(p<0.05)$ by T- test.

Table 3(C). The average values of the texture profile analysis of different reheating methods

\begin{tabular}{cccccc}
\hline \hline & Hardness(kg) & Springiness & Cohesiveness & Gumminess & Chewiness \\
\hline W.B. & $10.09 \pm 3.13$ & $0.65 \pm 0.12^{\mathrm{a}}$ & $0.55 \pm 0.04$ & $5.58 \pm 2.14$ & $3.71 \pm 1.73$ \\
C.O. & $14.38 \pm 7.00$ & $0.52 \pm 0.07^{\mathrm{b}}$ & $0.54 \pm 0.06$ & $7.80 \pm 4.13$ & $4.17 \pm 2.55$ \\
M.W. & $12.03 \pm 2.06$ & $0.56 \pm 0.08^{\mathrm{ab}}$ & $0.56 \pm 0.07$ & $6.85 \pm 1.90$ & $4.12 \pm 1.45$ \\
\hline
\end{tabular}

Data are mean \pm standard deviation.

W.B. $=$ Water-bath, C.O. $=$ Combination oven, M.W. $=$ Microwave .

${ }^{a b}$ Different letters are significantly different $(p<0.05)$ by Duncan's test.

\section{Sensory properties of sous-vide processed Galbi- jjim}

Pre-cooking procedure is necessary to remove the offflavor from the raw meat and improve of texture. Accordingly, beef short ribs were treated with boiled water under different time $(0,20,40$ and $60 \mathrm{~min})$. Through the first session of sensory evaluation, the optimal pre-cooking time of beef short ribs was determined (Table 4(A)). Interestingly, sensory scores in color, odor, saltiness, sweetness, chewiness and overall acceptance were high in both 20 and $60 \mathrm{~min}$ for pre-cooking. And, no pre-treatment for sous-vide processed Galbi-jjim gave the worst sensory scores in all sensory attributes $(p<0.05)$.

This can be explained that the pre-cooking time helped to decrease off-flavor of the meats and increase the palatability of final product. Regardless of this result, there could be limitation to be solved empirically. Even though the short beef ribs used for the sous-vide cooking were massively purchased from the same store in the same day, the original textures of the meats might be different one another due to the biased fat marbling, muscle density and uneven thickness of muscle and so on. Based on Jang's report (2005) which 20 minute pre-heating did not affect any significant quality changes in the attribute of beef, the optimal pre-cooking time for sous-vide Galbijjim was determined $60 \mathrm{~min}$ in this study.

Generally, sous-vide cooking is performed in both waterbath and steam/forced convection combination oven (Philip, 2000). In this study, the water-bath and combination oven were also used for sous-vide processed Galbi-jjim, and subsequent sensory tests were carried out to determine the optimal cooking method for sous-vide processed Galbi-jjim (Table 4(B)). The average sensory scores in juiciness and overall acceptance were significantly higher in waterbath-cooked Galbi-jjims than in combination oven $(p<0.05)$. This might be due to texture associated with the thermal conductivity, where in water heat transfer is higher than in air. And, the other sensory attributes between two cooking methods were not different.

Both re-heating method and internal temperature are basically important to contribute the sensory, hygiene (Song and Kim, 2007b) and microbiological safety. Thus, in this study, sous-vide processed Galbi-jjim products were reheated with different methods such as reheating at $90^{\circ} \mathrm{C}$ for $30 \mathrm{~min}$ in water bath, at $120^{\circ} \mathrm{C}$ for $30 \mathrm{~min}$ in combination oven and at $700 \mathrm{~W}$ for $3 \mathrm{~min}$ microwave, and the third sensory evaluation was performed. As shown in Table 4(C), there was no significant different in sen- 
Table 4(A). The average values of sensory evaluation of different pre-cook time

\begin{tabular}{rcccccc}
\hline \hline & Color & Odor & Salty & Sweety & Chewiness & $\begin{array}{c}\text { Overall } \\
\text { Acceptance }\end{array}$ \\
\hline $0 \mathrm{~min}$ & $4.42^{\mathrm{b}}$ & $3.82^{\mathrm{b}}$ & $3.92^{\mathrm{b}}$ & $4.17^{\mathrm{b}}$ & $4.17^{\mathrm{b}}$ & $4.50^{\mathrm{b}}$ \\
$20 \mathrm{~min}$ & $6.50^{\mathrm{a}}$ & $5.60^{\mathrm{a}}$ & $6.33^{\mathrm{a}}$ & $5.83^{\mathrm{ab}}$ & $6.33^{\mathrm{a}}$ & $6.67^{\mathrm{a}}$ \\
$40 \mathrm{~min}$ & $6.25^{\mathrm{a}}$ & $5.18^{\mathrm{ab}}$ & $5.42^{\mathrm{ab}}$ & $5.08^{\mathrm{bc}}$ & $5.58^{\mathrm{a}}$ & $5.67^{\mathrm{ab}}$ \\
$60 \mathrm{~min}$ & $7.08^{\mathrm{a}}$ & $6.70^{\mathrm{a}}$ & $6.33^{\mathrm{a}}$ & $6.50^{\mathrm{a}}$ & $6.50^{\mathrm{a}}$ & $6.25^{\mathrm{a}}$ \\
\hline
\end{tabular}

Data are mean \pm standard deviation.

${ }^{\mathrm{abc}}$ Different letters are significantly different $(p<0.05)$ by Duncan's test.

Table 4(B). The average values of sensory evaluation of different cooking methods

\begin{tabular}{cccccccc}
\hline \hline Cook & Color & Odor & Salty & Sweety & Chewiness & Juiciness & $\begin{array}{c}\text { Overall } \\
\text { Acceptance }\end{array}$ \\
\hline W.B. & $6.27 \pm 1.63$ & $6.30 \pm 1.49$ & $5.46 \pm 1.68$ & $5.73 \pm 1.52$ & $7.08 \pm 1.48$ & $6.81 \pm 1.47^{\mathrm{a}}$ & $6.97 \pm 1.44^{\mathrm{a}}$ \\
C.O. & $5.97 \pm 1.54$ & $5.76 \pm 1.81$ & $5.70 \pm 1.76$ & $5.32 \pm 1.63$ & $6.43 \pm 1.63$ & $5.78 \pm 1.51^{\mathrm{b}}$ & $5.65 \pm 1.62^{\mathrm{b}}$ \\
\hline
\end{tabular}

Data are mean \pm standard deviation.

W.B. = Water-bath, C.O. = Combination oven .

${ }^{a, b}$ Different letters are significantly different $(p<0.05)$ by T-test.

Table 4(C). The average values of sensory evaluation of different reheating methods

\begin{tabular}{cccccccc}
\hline \hline Reheated & \multirow{2}{*}{ Color } & Odor & Juiciness & Salty & Sweety & Chewiness & $\begin{array}{c}\text { Overall } \\
\text { Acceptance }\end{array}$ \\
\hline W.B. & $6.33 \pm 1.37^{\mathrm{a}}$ & $5.81 \pm 1.82^{\mathrm{a}}$ & $6.42 \pm 1.89^{\mathrm{a}}$ & $5.81 \pm 1.51^{\mathrm{a}}$ & $5.92 \pm 1.34^{\mathrm{a}}$ & $6.42 \pm 1.48^{\mathrm{a}}$ & $6.33 \pm 1.72^{\mathrm{a}}$ \\
C.O. & $6.00 \pm 1.54^{\mathrm{a}}$ & $5.56 \pm 1.73^{\mathrm{a}}$ & $6.50 \pm 1.38^{\mathrm{a}}$ & $5.92 \pm 1.44^{\mathrm{a}}$ & $5.86 \pm 1.61^{\mathrm{a}}$ & $6.50 \pm 1.32^{\mathrm{a}}$ & $5.92 \pm 1.40^{\mathrm{a}}$ \\
M.W. & $5.56 \pm 1.90^{\mathrm{a}}$ & $5.53 \pm 1.76^{\mathrm{a}}$ & $5.97 \pm 1.65^{\mathrm{a}}$ & $5.78 \pm 1.64^{\mathrm{a}}$ & $5.61 \pm 1.59^{\mathrm{a}}$ & $6.22 \pm 162^{\mathrm{a}}$ & $5.92 \pm 1.90^{\mathrm{a}}$ \\
\hline
\end{tabular}

Data are mean \pm standard deviation.

W.B. = Water-bath, C.O. = Combination oven, M.W. $=$ Microwave.

${ }^{\text {abc }}$ Different letters are significantly different $(p<0.05)$ by Duncan's test.

sory qualities $(p>0.05)$ among the reheating methods. This is well correlated with the results of textural analysis. Several reported that reheating methods have been performed in controlled water-bath (Armstrong and McIlveen, 2000; Díaz et al., 2008), microwave (GonzálezFandos et al., 2004; González-Fandos et al., 2005; Vaudagna et al., 2002) and steam convection oven (Song and Kim, 2007a; Song and Kim, 2007b). Reheating temperature and time were strictly specified as requirement of DHSS (2003) as follows: the internal temperature of the products removed from the refrigerator should be reached to $75^{\circ} \mathrm{C}$ within $30 \mathrm{~min}$. Accordingly, our study can be satisfied with international standard of sous-vide cooking and could be good possible application to RTE-type Korean traditional "Galbi-jjim".

\section{Acknowledgments}

This work was supported by a Korean Research Foundation grant funded by the Republic of Korea Government (NO. C00288).

\section{References}

1. Armstrong, G. A. and Mcllveen, H. (2000) Effect of prolonged storage on the sensory quality and consumer acceptance of sous vide meat-based recipe dishes. Food Qual. Prefer. 11, 377-385.

2. ACMSF (2004) Discussion paper. In: Advisory Committee on the Microbiological Safety of Food (ACMSF), HMSO, London, UK.

3. Creed, P. G. and Reeve, W. (1998) Principles and applications of sous vide processed foods. In: Sous vide and Cookchill Processing for the Food Industry. Ghazala S. (ed), Aspen Publishers, Gaithersburg, USA, pp. 25-56.

4. Creed, P. G. (1998) Sensory and nutritional aspects of sous vide processed foods. In: Sous vide and Cook-chill Processing for the Food Industry. Ghazala S. (ed), Aspen Publishers, Gaithersburg, USA, pp. 57-88.

5. Creed, P. G. (2000) Sous-vide - An Overview of the process. Available at: (accessed 30 July 2003).

6. Choi, T. D. (2004) Development and Globalization of Traditional Food Service Industry to Increase Demand for Domestic Agricultural Products. Korea Rural Economic Institute.

7. Díaz, P., Nieto, G., Garrido, M. D., and Bañón, S. (2008) Microbial, physical-chemical and sensory spoilage during the refrigerated storage of cooked pork loin processed by the 
sous vide method. Meat Sci. 80, 287-292.

8. DHSS (2003) Policy for Food Hygiene, Pest Control, Safety \& Quality/Code of Practice No 9, Process Control Cook Chill. In: Department of Health and Social Security Guidelines (DHSS), Version 3, London, UK, pp.1

9. ECFF (1996) Guidelines for the hygienic manufacture of chilled foods. In: European Chilled Food Federation (ECFF), London, UK.

10. FDA (2005) Food Code, Food Processing Criteria. In: Food and Drug Administration (FDA), USA, pp. 543-562

11. Galimpin-Johan, S. M. C., Russly, A .R., Jamilah, B., Man, Y. B. C., and Rusul, G. (2007) Pasteurization, development and storage of sous vide rending (spicy beef stew). J. Foodservice. 18, 251-263.

12. González-Fandos, E., Vilarino-Rodríguez, A., García-Linares, M. C., García-Arias, M.T., and García-Fernández, M. C. (2005) Microbiological safety and sensory characteristics of salmon slice processed by the sous vide method. Food Control 16, 77-85.

13. González-Fandos, E., García-Linares, M. C., VilarinoRodríguez, A., García-Arias, M. T., and García-Fernández, M. C. (2004) Evaluation of the microbiological safety and sensory quality of rainbow trout (Oncorhynchus mykiss) processed by the sous vide method. Food Control 21, 193-201.

14. Hauben, K. (1999) Sous vide cooking: State of art. In Proceedings of third European symposium on sous vide, Alma Sous Vide Competence Centre, Katholieke Universitet, Leuven, Belgium. 11-27.

15. Jang, J.D. and Lee, D.S. (2005) Development of a sous-vide packaging process for Korean seasoned beef. Food Control 16, 285-291.

16. Jang, J. D., Seo, G. H., Lyu, E. S., Yam, K. L., and Lee, D. S. (2006) Hurdle effect of vinegar and sake on Korean seasoned beef preserved by sous vide packaging. Food Control 17, 171-175.

17. Kim, G. T., Koo, K. M., Paik, H. D., Lyu, E. S., and Lee, D. S. (2001) Processing and storage of spinach products using cook-chill and sous vide methods. J. Kor. Soc. Food Sci.
Nutr. 30, 1095-1101.

18. Koo, K. M., Kim, H. W., Lee, D. S., Lyu, E. S., and Paik, H. D. (2008) Quality change during storage of cook-chilled soybean sprouts. Food Sci. Biotechnol. 17, 540-546.

19. Nyati, H. (2000) An evaluation of the effect of storage and processing temperatures on the microbiological status of sous vide extended shelf-life products. Food Control 11, 471-476.

20. Paik, H. D., Kim, H. J., Nam, K. J., Kim, C. J., Lee, S. E., and Lee, D. S. (2006) Effect of nisin of storage of sous vide processed Korean seasoned beef. Food Control 17, 994-1000.

21. Schelleken, M. (1996) New research issues in sous-vide cooking. Trends Food Sci. Technol. 7, 256-262.

22. Song, S. M. and Kim, H. Y. (2007a) Changes in Microbial Qualities and Sensory Characteristics of Boiled Potatoes and Imitation Crab in Soy Sauce as Prepared with the Cook-Chill System and Sous Vide Cook-Chill System. Korean J. Food Cookery Sci. 23, 252-260.

23. Song, S. M., Kim, H. Y., and Ko, S. H. (2007b) Changes in Microbial Qualities and Sensory Characteristics of Boiled Quail Egg and Fish Paste in Soy Sauce as Prepared with the Cook-Chill System and Sous Vide Cook-Chill System. Korean J. Food Cookery Sci. 23, 261-269.

24. Vaudagna, S. R., Pazos, A. A., Guidi, S. M., Sánchez, G., Carp, D. J., and Gonzalez, C. B. (2007) Effect of salt addition on sous vide cooked whole beef muscles from Argentina. Meat Sci. 79, 470-482.

25. Vaudagna, S. R., Sánchez, G., Neira, M. S., Insani, E. M., Gallinger, M. M., and Picallo, A. B. (2002) Sous vide cooked semitendinosus muscles: Effects of low temperature-long time (LT-LT) treatments on quality characteristics and storage stability of product. Int. J. Food Sci. Technol. 37, 425441.

26. Wang, S. H., Chang, M. H., and Chen, T. C. (2004) Shelf-life and microbiological profiler of chicken wing products following sous vide treatment. Poultry Sci. 3, 326-332.

$\overline{\text { (Received 2009.8.31/Revised 2009.11.24/Accepted 2009.12.1) }}$ 